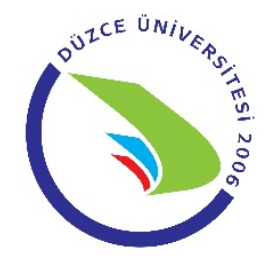

ORIJINAL MAKALE / ORIGINAL ARTICLE

\title{
Çocuklarda Görülen Diş Çürükleri ve Ebeveyn Sosyoekonomik Durumu Arasındaki İlişkinin Coğrafi Bazlı Verilerle Değerlendirilmesi
}

\author{
Zerrin ABBASOĞLU 國 1
}

\section{ÖZ}

Amaç: Bu çalışmanın amacı bir üniversite hastanesindeki kliniğe başvuran 6-15 yaş aralığındaki çocuk hastaların diş sağlığı durumlarının belirlenmesi ve coğrafi-referanslı sosyodemografik özelliklerle ilişkisinin saptanmasıdır.

Gereç ve Yöntemler: 6-15 yaş aralığındaki toplam 258 çocuk hastanın ilk muayeneleri yapılarak diş çürüğü skorları belirlendi. Hastaların ebeveynlerinden elde edilen bilgilerden faydalanılarak sosyoekonomik düzeylerinin belirlenmesi için coğrafi bazlı veriler incelendi. Sosyoekonomik statüsü ile diş çürüğü riski arasında anlamlı bir ilişki olup olmadığını anlamak için Poisson sayma regresyon modeli kullanıldı.

Bulgular: Bulgular, düşük sosyoekonomik seviyeden gelen hastalarda görülecek çürük sayısının daha yüksek olacağı savını destekler niteliktedir. Örneklemdeki ekonomik seviyesi en düşük mahalleden gelen bir hastadaki diş çürüğü sayısı en yüksek mahalleden gelen bir hastaya göre daha yüksek olduğu bulunmuştur. Ortalama konut kirası seviyesi İstanbul genelinde en düşük olan bir mahalleden gelen bir hastadaki diş çürüğü sayısı, ortalama konut kirası seviyesi İstanbul genelinde en yüksek olan bir mahalleden gelen bir hastaya göre ortalama 1,5 daha yüksek bulunmuştur. Mahalle bazında ortalama satılık konut fiyatlarına baktığımızda ise, bu fark ortalama 0,89 daha yüksek çıkmıştır.

Sonuç: Bir veri toplama şekli olan coğrafi bazlı veriler, toplum ağız sağlığı araştırmalarında daha güvenilir sonuçlara ulaşılabilmesi için önemli bir katkı sağlayacaktır. Bu yeni veri toplama tekniği, ülkemizdeki sosyoekonomik statü ve cocuk ağız sağlığı arasındaki ilişkinin dışsal geçerliliğini güçlendirmiştir.

Anahtar Kelimeler: Diş çürükleri; coğrafya; çocuk.

\section{Assessment of the Relationship among Dental Caries of Children and Socioeconomic Status of Their Parents with Geography-Based Data}

\begin{abstract}
Aim: The aim of this study was to assess the dental health of 6-15 year old children and to analyze with geographybased sociodemographic features in the clinic of an university hospital.

Material and Methods: Dental caries scores of 258 children between ages 6-15 by performing first oral examination were determined. The geography-based data were analyzed to determine their socioeconomic status by making use of information obtained from parents of patients. Multi-variable Poisson regression model was run to understand whether there is a significant relationship between socioeconomic status and risk of dental caries.

Results: Findings support the assertion that lower levels of socioeconomic status are associated with higher counts of dental caries incidence. A child patient coming from a neighborhood averaging the lowest level of residential rent levels has an expected dental caries count of 1.5 higher than a child patient coming from a neighborhood the highest level of average rent levels. The number of caries count in a child patient coming from a neighborhood with the lowest level of residential real estate value level has an expected count 0.89 higher than from a child patient coming from a neighborhood with the highest level of average residential real estate value.

Conclusion: The geography-based data, which is a data acquisition technique, will make a great contribution to be able to achieve more reliable results for community oral health researches. This new data acquisition technique increases the external validity of the association between socioeconomic status and oral health in children in Turkey.
\end{abstract}

Keywords: Dental caries; geography; child.

1 Yeditepe Üniversitesi, Diş Hekimliği Fakültesi, Klinik Bilimler Bölümü, Çocuk Diş Hekimliği AD, İstanbul, Türkiye

Sorumlu Yazar / Corresponding Author: Zerrin ABBASOĞLU, e-mail: zerrin.abbasoglu@gmail.com

Geliş Tarihi / Received: 13.03.2020, Kabul Tarihi / Accepted: 09.05.2020 


\section{GIRIȘ}

Diş çürüğü, dișin kimyasal yapısında ortaya çıkan, geri dönüşü olmayan, multifaktöriyel bir hastalıktır. Bulaşıcı bir enfeksiyon hastalığ 1 olarak tanımlanan diş çürüğü, özellikle çocuklar için başlıca ağız sağlığı sorunudur (13).

Diş çürüğü etiyolojisinde pek çok faktör yer almaktadır. Çürük oluşumu ve ilerlemesinde bakteriyel flora, beslenme alışkanlıkları, fluora maruz kalma, ağız hijyeni, tükürük akıș hızı, tükürük kompozisyonu ve diş yapısının etkisi dışında, çevresel faktörlerin etkileşimi rol oynamaktadır (4). Çevresel faktörler arasında yer alan düşük sosyo-ekonomik çevre ve eğitim yetersizliği gibi faktörlerin çocuklarda çürük görülmesinde etkili olduğu bilinmektedir. Düşük ve orta gelir seviyesine sahip ülkelerde yaşayan çocuklarda diş çürüğü prevalansının daha yüksek olduğu rapor edilmiştir (5). Brezilya, Japonya, İsveç ve İran gibi ülkelerde çocuklarda diş çürüğüne neden olan faktörler arasında sosyoekonomik durum ve ebeveynlerin eğitim düzeyi değerlendirilmiştir (6-9). Amerika Birleşik Devletleri'nde yapılan bir araştırmada düşük eğitim ve gelir seviyesine sahip ebeveynlerin çocuklarında daha fazla çürük oluşumunun gözlemlendiği ve akranlarına göre daha kilolu oldukları bulunmuştur (10). Japonya' da 2019 yılında yapılan bir araştırmada ise ailenin büyükleri (büyükanne ve büyükbaba) ile beraber yaşayan çocukların gelir seviyesinin daha düşük olduğu ve diş çürüğü riskinin bunlara bağlı olarak arttığı bildirilmiştir (11). Benzer şekilde Türkiye'de de çocuklarda diş çürüğü ve sosyoekonomik faktörlerin incelendiği araştırmalar yapılmıştır (12-17). İstanbul' da 2-5 yaş aralığındaki 200 çocuk üzerinde yapılan bir araştırmada, yüksek gelir seviyesine sahip biberonla beslenen çocukların süt dişlerindeki dmft (çürük, çekilmiş, dolgulu diş) değerinin düşük olduğu bulunmuştur (18). Manisa' da yapılan bir araştırmada ise 11-12 yaş aralığındaki 744 çocuğun ağıziçi muayeneleri yapılarak çürük diş sayıları belirlenmiş ve sosyodemografik özelliklerini tanımlayan anket formu doldurtulmuştur. Araştırmanın sonuçlarına göre düşük gelir seviyesine sahip çocukların ortalama çürük diş sayılarının yüksek olduğu bulunmuştur (19).

Sosyodemografik süreçlerin coğrafyasına dair ilgi, coğrafi-bazlı verilerin daha fazla kullanılabilirliği ile önem kazanmıștır (20). Bu verilerin elde edilmesinde sıklıkla kişilerin beyanları kullanılsa da, son yıllarda yapılan araştırmalarda coğrafi-bazlı sosyodemografik verilerden faydalanılmaya başlanmıştır $(7,9)$. Coğrafibazlı verilerle elde edilen bilgiler araştırmalar için önem taşımaktadır. Çünkü kişilerin sosyodemografik durumlarını daha gerçekçi olarak gösterebilmektedir (9). $\mathrm{Bu}$ çalışmanın amacı kliniğimize başvuran 6-15 yaş aralığındaki çocuk hastaların ağız-diş sağlığı durumlarının belirlenmesi ve coğrafi-bazlı sosyodemografik özelliklerle ilişkisinin saptanmasıdır.

\section{GEREC VE YÖNTEMLER}

$\mathrm{Bu}$ çalışma, Yeditepe Üniversitesi Diş Hekimliği Fakültesi Çocuk Diş Hekimliği diş tedavileri için başvuran, daha önce herhangi bir diş kliniğginde tedavi olmamış, sistemik ve genetik hastalığı olmayan, ortodontik tedavi görmemiş olan ve 6-15 yaş aralığındaki toplam 258 çocuk hasta (108 kız ve 150 erkek) üzerinde gerçekleştirilmiştir. Mayıs ve Eylül 2019 tarihleri arasında kliniğimize başvuran 342 hastadan, kriterlere uygunluk sağlayan ve gönüllü olan 258 hasta çalışmaya dahil edilmiştir. $\mathrm{Bu}$ araştırmada, evrenin \%75,43'üne ulaşılmıştır. Araştırma, Sabancı Üniversitesi Etik Kurulu tarafından onaylanmıştır (FASS-2019-07). Araştırma ve yayın etiğine uygun olarak, çalışmaya dâhil edilen hastaların ebeveynlerine araştırmanın amacı ve içeriği anlatılmıştır ve gönüllü olarak çalışmaya katıldıklarına dair bilgilendirilmiş onam formu imzalatılmıştır.

Çalışmaya dâhil edilen çocukların ebeveynleri ile yapılan anketler ile eğitim düzeyleri belirlenmiştir. Ebeveynlerin ekonomik gelir düzeyleri hasta kayıt sürecinde beyan ettikleri mahalle adresleri üzerinden elde edilmiştir. Elde edilen bu coğrafi bazlı veriler, Yıldırım'ın (21) doktora tez araştırması ve proje için emlak web sitelerinden topladığı mahalle bazında ortalama kiralık ve satılık metrekare ev fiyatları ile eşleştirilmiş ve buradan da ebeveynlerin ekonomik durumu ana değişkeni elde edilmiştir.

Çocukların ağız içi muayeneleri, ebeveyn onayı ile dental ünitlerde, oturur pozisyonda, steril ayna ve sond kullanılarak reflektör 1 şı ğı altında yapılmıştır. Çocukların dental muayene ve diş çürükleri tespitinde Dünya Sağlık Örgütü (WHO) 2003 Kriterleri kullanılmıştır. Çürük, dolgulu ve eksik dişler belirlenerek sürekli dişlerdeki DMFT (çürük, çekilmiş, dolgulu diş) ve süt dişlerindeki dmft (çürük, çekilmiş, dolgulu diş) skorları kaydedilmiştir.

\section{İstatistiksel Analiz}

$\mathrm{Bu}$ çalışmada bir hastanın sosyoekonomik statüsü ile DMFT+dmft sayıları arasında anlamlı bir ilişki olup olmadığını test etmek için Poisson sayma regresyon modeli kullanılmıștır. Bu modelin kullanılmasında iki ana etken vardır. İlk olarak ağızdaki çürük sayısı ölçümlerinden edilen alt taraftan 0 ile, üst taraftan ise 20 ile sınırlı tam sayılardır. Bu tür 'sayma' vakalarında Poisson modelleri uygun istatistiksel modeldir (22). Ayrıca bu modellere ana açıklayıcı değişkene (sosyoekonomik statü) ek olarak istenilen kontrol değişkenleri de eklenebilmektedir. Örneklemin rasgele toplanamadığı çalıșmalarda, kontrol değișkenlerinin eklenmesi nedensel çıkarımın daha sağlıklı yapılmasını sağlamaktadır. İstatistiksel analizler, Stata 14 programı kullanılarak yapılmıştır.

\section{BULGULAR}

Hasta ebeveynlerinin ekonomik statüsü ile hastanın dışındaki DMFT + dmft sayısı arasındaki ilişkiyi inceleyen istatistiki analizler Tablo 1'de sunulmaktadır. Tablo 2'de ise $\mathrm{K} 1$ ve $\mathrm{S} 1$ modelleri mahalledeki ortalama kiralık (K) ve satılık (S) metrekare konut fiyatıyla toplam diş çürüğü sayısı arasında iki değişkenli regresyon sonuçlarını göstermektedir. K2, K3 ve S2, S3 modelleri ise, K1 ve S1 modellerine kontrol değişkenleri ekleyerek sonuçların sağlamlığını incelemektedir.

$\mathrm{K} 1$ ve S1 modellerinin sonuçlarına göre gelir seviyesi yükseldikçe, hastada görülmesi beklenen çürük sayısı azalmıştır. Şekil 1, kira oranlarıyla ölçülen farklı gelir seviyeleri ile hastada beklenen ortalama DMFT+dmft insidanslarını \%95 güven aralıkları ile göstermektedir. K1 modeli, örneklemdeki en düşük kira grubunda dahil bir mahallede yaşayan bir hastada ortalama 4 (\%95 güven 
Tablo 1. Hastaların diş çürüğü insidansı ve sosyodemografik özelliklerine göre dağılımı

\begin{tabular}{|c|c|c|c|c|}
\hline \multicolumn{2}{|c|}{$\begin{array}{c}\text { Sosyodemografik özellikler } \\
\end{array}$} & $\mathbf{n}$ & $\%$ & Kümülatif (\%) \\
\hline DMFT+dmft [0-20] & Ort $\pm s s$ & \multicolumn{3}{|c|}{$3,3 \pm 4,3$} \\
\hline \multirow[t]{4}{*}{ Yaş } & Ort $\pm s s$ & \multicolumn{3}{|c|}{$9,5 \pm 2,4$} \\
\hline & $6-9$ & 96 & 46,4 & 46,4 \\
\hline & $10-12$ & 78 & 37,7 & 84,1 \\
\hline & $13-15$ & 33 & 15,9 & 100 \\
\hline \multirow{2}{*}{ Cinsiyet } & $\mathrm{K} 1 \mathrm{Z}$ & 132 & 59,5 & 69,5 \\
\hline & Erkek & 90 & 40,5 & 100 \\
\hline \multirow[t]{4}{*}{ Hasta doğum sırası } & 1 & 105 & 50,5 & 50,5 \\
\hline & 2 & 82 & 39,4 & 89,9 \\
\hline & 3 & 14 & 6,7 & 96,6 \\
\hline & 4 ve üstü & 6 & 3,3 & 100 \\
\hline \multirow[t]{3}{*}{ Anne eğitim düzeyi } & Ortaokul ve alt1 & 35 & 16,9 & 16,9 \\
\hline & Lise ve alt1 & 122 & 58,9 & 75,9 \\
\hline & Üniversite & 50 & 24,2 & 100 \\
\hline \multirow[t]{2}{*}{ Anne medeni durumu } & Evli & 198 & 95,2 & 95,2 \\
\hline & Bekar & 10 & 4,8 & 100 \\
\hline \multicolumn{2}{|c|}{ Toplam } & 207 & 100 & \\
\hline
\end{tabular}

DMFT+dmft: Sürekli dişlerdeki çürük, çekilmiş, dolgulu diş sayısı + süt dişlerindeki çürük, çekilmiş, dolgulu diş sayısı; n: Hasta sayısı; Ort \pm ss: Ortalama \pm standart sapma

Tablo 2. Coğrafi-bazlı sosyoekonomik statü ile diş çürüğü insidansı arasındaki ilişki

\begin{tabular}{|c|c|c|c|c|c|c|}
\hline Model No & K1 & $\mathbf{K} 2$ & K3 & S1 & $\mathrm{S} 2$ & S3 \\
\hline \multirow{2}{*}{$\begin{array}{l}\text { Mahalle Ortalama } \\
\text { Kiralık Konut Fiyatı }\end{array}$} & $-0,05 * *$ & $-0,01$ & $-0,02$ & & & \\
\hline & $(0,02)$ & $(0,02)$ & $(0,02)$ & & & \\
\hline \multirow{2}{*}{$\begin{array}{l}\text { Mahalle Ortalama } \\
\text { Satılık Konut Fiyatı }\end{array}$} & & & & $-0,03+$ & 0,01 & 0,00 \\
\hline & & & & $(0,02)$ & $(0,02)$ & $(0,02)$ \\
\hline \multirow{2}{*}{$\begin{array}{l}\text { Annenin Eğitim } \\
\text { Düzeyi }\end{array}$} & & $-0,27 * *$ & & & $(0,27)$ & \\
\hline & & $(0,06)$ & & & $(0,06)$ & \\
\hline \multirow{2}{*}{$\begin{array}{l}\text { Annenin Medeni } \\
\text { Durumu }\end{array}$} & & 0,17 & 0,15 & & $0,19+$ & 0,16 \\
\hline & & $(0,11)$ & $(0,11)$ & & $(0,11)$ & $(0,11)$ \\
\hline \multirow{2}{*}{$\begin{array}{l}\text { Hastanın Doğum } \\
\text { Sırası }\end{array}$} & & $-0,14^{*}$ & $-0,13^{*}$ & & $-0,14^{*}$ & $-0,13^{*}$ \\
\hline & & $(0,06)$ & $(0,06)$ & & $(0,06)$ & $(0,06)$ \\
\hline \multirow{2}{*}{$\begin{array}{l}\text { Hasta Cinsiyeti } \\
(1=\text { Kadın, 2=Erkek) }\end{array}$} & & $-0,23^{* *}$ & $-0,22 * *$ & & $-0,24^{* *}$ & $-0,22^{* *}$ \\
\hline & & $(0,08)$ & $(0,08)$ & & $(0,08)$ & $(0,08)$ \\
\hline \multirow[t]{2}{*}{ Hasta Yaşı } & & $-0,12 * *$ & $-0,10^{* *}$ & & $-0,12 * *$ & $-0,10^{* *}$ \\
\hline & & $(0,02)$ & $(0,01)$ & & $(0,02)$ & $(0,01)$ \\
\hline \multirow[t]{2}{*}{ Sabit } & $1,39 * *$ & $3,13 * *$ & $2,42 * *$ & $1,32 * *$ & $3,06 * *$ & $2,35 * *$ \\
\hline & $(0,08)$ & $(0,24)$ & $(0,17)$ & $(0,09)$ & $(0,24)$ & $(0,17)$ \\
\hline $\mathrm{n}$ & 222 & 207 & 208 & 222 & 207 & 208 \\
\hline 11 & $-873,1$ & $-729,4$ & $-740,1$ & $-839,3$ & $-729,5$ & $-740,6$ \\
\hline LR Testi & $\begin{array}{c}\chi^{2}(1)=7,1 \\
p=0,078\end{array}$ & $\begin{array}{c}\chi^{2}(6)=88,1 \\
p<0,001\end{array}$ & $\begin{array}{c}\chi^{2}(5)=73,1 \\
p<0,001\end{array}$ & $\begin{array}{c}\chi^{2}(1)=2,7 \\
p=0,098\end{array}$ & $\begin{array}{c}\chi^{2}(6)=87,9 \\
p<0,001\end{array}$ & $\begin{array}{c}\chi^{2}(5)=72,1 \\
p<0,001\end{array}$ \\
\hline Pseudo- $\mathrm{R}^{2}$ & 0,004 & 0,057 & 0,047 & 0,016 & 0,057 & 0,046 \\
\hline
\end{tabular}

aralığı (GA): 3,35-4,65) DMFT+dmft sayımı tahmin ederken, örneklemdeki en yüksek kira ortalaması grubuna dahil bir mahallede yaşayan bir hastada bu sayı ortalama 2,5’e (\%95 GA: 1,96-3,04) düşmektedir. Başka bir deyişle, örneklemdeki ekonomik seviyesi en düşük mahalleden gelen bir hastadaki DMFT + dmft sayıs en yüksek mahalleden gelen bir hastaya göre 1,5 daha yüksek bulunmuştur.

Metrekare başına ortalama satılık konut fiyatını baz alan S1 modelinde ise bu etki daha az ortaya çıkmaktadır.
Şekil 2, satılık konut fiyatlarıyla ölçülen gelir seviyesi ile hastada beklenen ortalama DMFT $+\mathrm{dmft}$ insidanslarını öngören S1 modeli sonuçlarını \%95 güven aralıkları ile göstermektedir. S1 modeli, örneklemimizdeki en düşük satılık konut değerine sahip gruba dahil bir mahallede yaşayan bir hastada ortalama 3,78 (\%95 GA: 3,09-4,42) $\mathrm{DMFT}+\mathrm{dmft}$ sayımı ön görürken, örneklemdeki en yüksek konut satış ortalaması grubuna dahil bir mahallede yaşayan bir hastada bu sayı 2,89'a (\%95 GA: 2,40-3,37) düşmektedir. Başka bir deyişle, örneklemdeki 
ekonomik seviyesi en düşük mahalleden gelen bir hastadaki DMFT+dmft sayısı en yüksek mahalleden gelen bir hastaya göre 0,89 daha yüksek bulunmuştur.

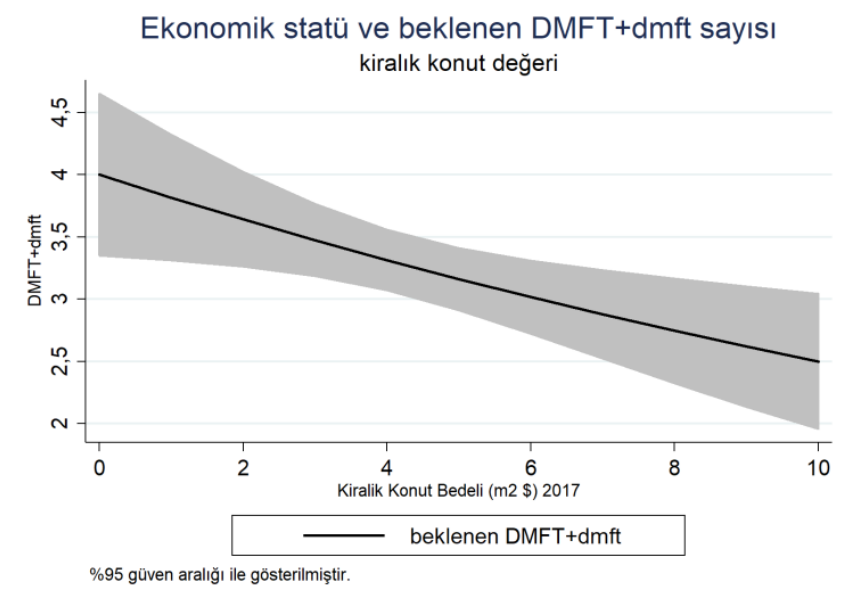

Şekil 1. Mahalle ortalama emlak kira oranları ve çürük insidans1

Kiralık ve satılık konut modellerinde kullanılan annenin eğitim düzeyi ve medeni durumu, hastanın cinsiyeti, yaşı ve doğum sırası gibi kontrol değişkenleri eklendiği zaman ekonomik statü değişkenleri istatistiksel olarak anlamlılığını kaybetmiştir.

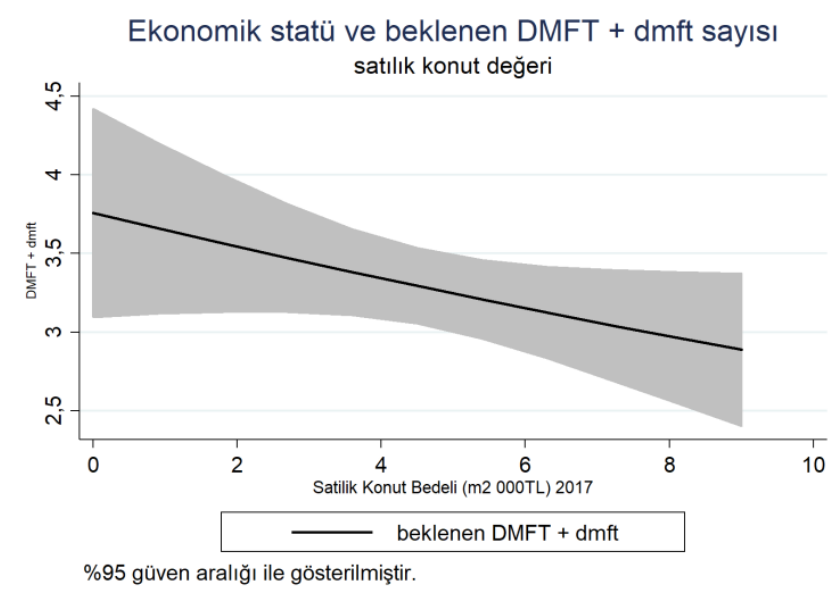

Şekil 2. Mahalle ortalama emlak satış fiyatları ve çürük insidans1

\section{TARTIŞMA}

Diş çürüğü, coğrafik, sosyolojik, ekonomik, biyolojik, davranışsal ve fizyolojik faktörlerin oluşturduğu çevresel faktörler ile etkileşimi olarak ortaya çıkmaktadır (23). Dolayısıyla bir bireyin çürük durumu, çevresel faktörlerin yaşam boyu süregelen birikimini yansıtmaktadır (24). Bu nedenle farklı coğrafik bölgelerde yaşayan çocuklarda çürük görülme sıklığı değişkenlik göstermektedir (25). Bölgelerdeki eğitim seviyesi ve gelir düzeyi arttıkça diş çürüğü oluşumunda etkili olan beslenme şekli, ağız hijyenini doğru şekilde sağlayabilme gibi faktörler olumlu yönde etkilenecektir. Gelir seviyesi düştük toplumlarda, kolay ulaşılabilir olduğu için hazır ve işlenmiş gıdaya yönelim artmaktadır. $\mathrm{Bu}$ karyojenik beslenme şekli de diş çürügü oluşumunu arttırmaktadır. Yine benzer şekilde düşük sosyoekonomik seviyede olan bireylerin ağız hijyen ürünlerine yeterli miktarda sahip olamamaları ve ağız hijyenini sağlama konusunda bilgi yetersizliklerinden dolayı diş çürüğü oluşumu daha fazla görülmektedir (3,7-9). Buna göre, biyolojik faktörlerle birlikte çevresel ve fizyolojik faktörlerin çürük prevalansı üzerindeki etkilerinin birlikte değerlendirildiği araştırmalar önem kazanmaktadır. Brezilya'da 2006, 2016, 2017 ve 2019 yıllarında yapılan araştırmalarda, kişilerin sosyoekonomik statüleri araştırmacılar tarafından hazırlanan anket soruları üzerinden elde edilen verilerle, düşük sosyoekonomik statü ile diş çürüğü görülme riski arasında istatiksel olarak anlamlı bir ilişki saptanmıştır (8,26-28). Japonya, Hindistan ve Amerika Birleşik Devletleri gibi diğer ülkelerde ise sosyoekonomik seviyesi düşük ailelerin çocuklarında dmft ve DMFT skorlarının daha yüksek olduğu bulunmuştur $(10,11,29)$. Benzer şekilde Türkiye'nin farklı illerinde yapılan araştırmalara göre çevresel bir etiyolojik faktör olan sosyoekonomik seviye ile çocuklarda diş çürügü oluşumu arasında negatif bir korelasyon olduğu saptanmıştır (12-17). Araştırmamızın sonuçları da Dünya'da ve Türkiye'de yapılmış çalışmalarla benzerlik göstermektedir.

Dünyada ve Türkiye'de yapılan birçok araştırmada sosyoekonomik faktör, kişilerin gelir beyanları üzerinden değerlendirilmiştir (6-19). Bu çalışmada ise hastaların yaşadığ1 mahalleler sosyoekonomik gelir göstergesi olarak kullanılmıştır. İsveç’te 2019 yılında yapılan araştırmada ebeveynlerin jeokod verileri kullanılarak sosyoekonomik seviyeleri belirlenmiş ve bunlar çocukların diş çürüğü görülme riski ile ilişkilendirilmiştir (9). Benzer şekilde İran'da 2019 yılında yapılan bir araştırmada Ulusal Veri Bankası'ndan elde edilen coğrafi veriler kullanılarak çocukların sosyoekonomik statülerinin diş çürüğü oluşumundaki etkisine bakılmıştır (7). Bizim çalışmamızda ise bir tez çalışması sonucunda oluşan projeden elde edilen istatiksel coğrafi bazlı veriler aracılığı ile kişilerin en doğru sosyoekonomik düzey bilgilerine erişilmiştir.

Sosyodemografik verilerin elde edilmesi için görüşme, anket yöntemi, gözlem ve belge-kaynak tarama yöntemi gibi teknikler günümüzde kullanılmaktadır. Görüşme ve gözlem yöntemleri, cevaplama oranının en yüksek olduğu yöntemler olmasına karşın pahalı, zaman alıcı ve yanlılığa açık olması gibi dezavantajlara sahiptir. Sağlık alanında en çok kullanılan yöntem, anket tekniğidir (3033). Bunun sebebi kolay, ucuz ve büyük örneklemlerden veri toplanabilmesidir. Fakat verilerin doğruluğunun kişilerin beyanına dayanması ve anket sorularının tam doldurulmaması en büyük dezavantajları arasındandır. Belgesel kaynak tarama yönteminde ise var olan belge, rapor veya kayıtlar incelenerek kişiler hakkında bilgi elde edilmektedir. $\mathrm{Bu}$ yöntemin diğer yöntemlere göre en büyük avantajı bilgilerin güvenirliliğidir. Dezavantajı ise veriye ulaşılabilirliliğin zor olmasıdır. Araştırmamızda kullandığımız coğrafi-bazlı veriler, belge ve kaynaklardan elde edilen verilerle oluşturulmuştur (3033). Coğrafi bazlı verilerin kullanılması, kişilerin beyanları gibi diğer veri toplama şekillerinde karşılaşılabilecek problemlere karşı bir alternatif oluşturmaktadır. Çünkü sosyal psikoloji, kişilerin olduklarından daha üst seviyede gelir gösterme eğilimi olduğunu söylemektedir. Araştırmamızda bulguların istatistiksel olarak anlamlı çıkması, coğrafi bazlı 
ekonomik veriler konusuna sağlık çalışmalarına eğilimi cesaretlendirir niteliktedir.

Satılık konut metrekare fiyatı ile çürük sayısı arasındaki ilişkinin istatiksel anlamlılığının nispeten zayıf olması, verinin toplandığ 2017 ve 2018 senelerinde İstanbul Anadolu yakasının kentsel dönüşümden geçiyor olmasıyla da açıklanabilir. $\mathrm{Bu}$ kentsel dönüşüm çerçevesinde normalde daha düşük metrekare fiyatına sahip mahallelerin birçoğunun içine lüks emlak projeleri inşa edilmiş, bu da o mahallenin hem sosyoekonomik yapısını daha heterojen hale getirmiş hem de satılık emlak fiyatlarını yukarı çekmiştir. Ancak, kentsel dönüşüm aynı zamanda konut stok fazlası üretmiştir. Bu durum kira fiyatlarında, ortalamanın üstünde olan birkaç gelir seviyesi yüksek muhit dışında, benzer bir yukarı harekete sebep olmamıştır. Kentsel dönüşümün yol açtığ 1 bu sosyal mobilite ve yer değiştirmeye rağmen sonuçların anlamlı çıkması, sosyoekonomik seviye ölçümlerinde coğrafi bazlı verinin kullanılmasının önemini arttırmaktadır. Bu çalışma aynı zamanda Türkiye'de çocuk diş sağlığında coğrafi bazlı verinin kullanıldığı ilk araştırmadir.

$\mathrm{Bu}$ araştırmanın coğrafi bölge olarak kapsamı İstanbul ilidir ve hasta profili bir üniversite ile sınırlıdır. Annenin eğitim düzeyi ve medeni durumu gibi bazı sosyodemografik bilgiler de kişilerin beyanı ile sınırlı kalmaktadır.

\section{SONUÇ}

Diş çürüğü oluşumuna neden olabilecek çevresel faktörlerden biri olan düşük sosyoekonomik durum, bir risk faktörü olarak çocukta diş sağlığını olumsuz yönde etkilemektedir. Diş çürüğünün kompleks ve multifaktöriyel etiyolojiye sahip olması nedeniyle, birçok risk faktörünün birlikte incelenmesi gerekmektedir. Bunun için daha fazla güvenilir veriler (coğrafi bazlı veriler) ile değerlendirilen çalışmalara ihtiyaç duyulmaktadır. Bu açıdan yeni bir veri toplama şekli olan coğrafi-bazlı veriler, toplum ağız diş sağlı̆̆ araştırmalarında Türkiye bazında önemli bir katkı sağlayacaktır.

\section{KAYNAKLAR}

1. Saxena D, Li Y, Caufield PW. Identification of unique bacterial gene segments from Streptococcus mutanswith potential relevance to dental caries by subtraction DNA hybridization. J Clin Microbiol. 2005; 43(7): 3508-11.

2. Tao R, Jurevic RJ, Coulton KK, Tsutsui MT, Roberts MC, Kimball JR, et al. Salivary antimicrobial peptide expression and dental caries experience in children. Antimicrob Agents Chemother. 2005; 49(9): 3883-8.

3. Petersen PE. The World Oral Health Report 2003: continuous improvement of oral health in the 21st century-- the approach of the WHO Global Oral Health Programme. Community Dent Oral Epidemiol. 2003; 31(1): 3-23.

4. Azevedo LF, Pecharki GD, Brancher JA., Cordeiro CA Jr, Medeiros KG, Antunes AA, et al. Analysis of the association between lactotransferrin (LTF) gene polymorphism and dental caries. J. Appl. Oral Sci. 2010; 18(2): 166-70.
5. Anopa Y, Conway DI. Exploring the costeffectiveness of child dental caries prevention programmes. Are we comparing apples and oranges? Evid Based Dent. 2020; 21(1): 5-7.

6. Tanaka K, Miyake Y, Sasaki S, Hirota Y. Socioeconomic status and risk of dental caries in Japanese preschool children: the Osaka Maternal and child health study. J Public Health Dent. 2013; 73(3): 217-23.

7. Ghasemianpour M, Bakhshandeh S, Shirvani A, Emadi N, Samadzadeh H, Moosavi Fatemi N, et al. Dental caries experience and socio-economic status among Iranian children: a multilevel analysis. BMC Public Health. 2019; 19(1): 1-8.

8. Chaffee BW, Rodrigues PH, Kramer PF, Vítolo MR, Feldens CA. Oral health-related quality-of-life scores differ by socioeconomic status and caries experience. Community Dent Oral Epidemiol. 2017; 45(3): 21624.

9. André Kramer AC, Pivodic A, Hakeberg M, Östberg AL. Multilevel analysis of dental caries in Swedish children and adolescents in relation to socioeconomic status. Caries Res. 2019; 53(1): 96-106.

10. Marshall TA, Eichenberger-Gilmore JM, Broffitt BA, Warren JJ, Levy SM. Dental caries and childhood obesity: roles of diet and socioeconomic status. Community Dent Oral Epidemiol. 2007; 35(6): 44958.

11. Morita A, Matsuyama Y, Isumi A, Doi S, Ochi M, Fujiwara T. Association between grandparent coresidence, socioeconomic status and dental caries among early school-aged children in Japan: a population-based prospective study. Sci Rep. 2019; 9(1): 1-8.

12. Koçanalı B, Topaloğlu A, Çoğulu D. Çocuklarda diş çürüğüne neden olan faktörlerin incelenmesi. The Journal of Pediatric Research. 2014; 1(2): 76-9.

13. Ayrancı Ü. Bir grup ilkokul öğrencisinde diş çürüğü saptama araştırmas1. Sted. 2005; 14(3): 50-4

14. Ulu Güzel KG, Akyildiz M, Doğusal G, Keleş S, Sönmez I. Evaluation of oral health status of children in pretreatment and after treatment for 18 month. Cent Eur J Public Health. 2018; 26(3): 199-203.

15. Namal N, Vehit HE, Can G. Risk factors for dental caries in Turkish preschool children. J Indian Soc Pedod Prev Dent. 2005; 23(3): 115-8.

16. Namal N, Yüceokur AA, Can G. Significant caries index values and related factors in 5-6-year-old children in Istanbul, Turkey. East Mediterr Health J. 2009; 15(1): 178-84.

17. Öztürk AB, Sönmez B. Güneydoğu Anadolu kırsalında yaşayan çocuklarda ağız ve diş sağlığı değerlendirilmesi: kesitsel saha çalışması sonuçları. Konuralp Tip Dergisi. 2016; 8(3): 195-201.

18. Münevveroğlu AS, Koruyucu M, Seymen F. 2-5 yaş arası çocuklarda erken çocukluk çürüklerine neden olan risk faktörleri. İstanbul Üniversitesi Diş Hekimliği Fakültesi Dergisi. 2014; 48(1): 19-30.

19. Şahin Büyük D, Çetinkaya A, Özmen D, Tayhan A, Uyar F. 11-12 yaş grubu çocukların ağız ve diş sağlığı konusundaki bilgi ve davranışlarının değerlendirilmesi. DEUHEFED. 2018; 11(2): 78-86 
20. Voss PR. Demography as a spatial social science. Popul Res Policy Rev. 2007; 26(6): 457-76.

21. Yıldırım K. Continuous clientelism, persuasion and preference change in Turkey [PhD Theses]. Istanbul: Koc University; 2016.

22. Long JS. Regression models for categorical and limited dependent variables. USA: Sage Publications; 997.

23. Zero DT. Dental caries process. Dental Clinics North America.1999; 43(4): 635-64.

24. Nicolau B, Marcenes W, Bartley M, Sheiham A. A life course approach to assessing causes of dental caries experience: the relationship between biological, behavioural, socio-economic and psychological conditions and caries in adolescents. Caries Res. 2003; 37(5): 319-26.

25. Pine C, Burnside G, Craven R. Inequalities in dental health in the north-west of England. Com Dent Health. 2003; 20(1): 55-6.

26. Oliveira AF, Chaves AM, Rosenblatt A. The influence of enamel defects on the development of early childhood caries in a population with low socioeconomic status: a longitudinal study. Caries Res. 2006; 40(4): 296-302.

27. Engelmann JL, Tomazoni F, Oliveira MD, Ardenghi TM. Association between dental caries and socioeconomic factors in schoolchildren: a multilevel analysis. Braz Dent J. 2016; 27(1): 72-8.

28. Tomazoni F, Vettore MV, Mendes FM, Ardenghi TM. The association between sense of coherence and dental caries in low social status schoolchildren. Caries Res. 2019; 53(3): 314-21.

29. Gokhale N, Nuvvula S. Influence of socioeconomic and working status of the parents on the incidence of their children's dental caries. J Nat Sci Biol Med. 2016; 7(2): 127-9.

30. Gill P, Stewart K, Treasure E, Chadwick B. Methods of data collection in qualitative research: interviews and focus groups. Br Dent J. 2008; 204(6): 291-5.

31. Piwowar HA, Becich MJ, Bilofsky H, Crowley RS. caBIG Data sharing and intellectual capital workspace. Towards a data sharing culture: recommendations for leadership from academic health centers. PLoS Med. 2008; 5(9): e183.

32. Alsheikh-Ali AA, Qureshi W, Al-Mallah MH, Ioannidis JP. Public availability of published research data in high-impact journals. PLoS One. 2011; 6(9): e24357.

33. Sutton J. Qualitative research: Data collection, analysis, and management. Can J Hosp Pharm. 2015; 68(3): 226-31. 